however, do little to improve the condition of elderly patients with severe valvular heart disease, and some will remain house bound or bedfast. Moreover, domiciliary care for these patients, who may survive for a long time in chronic heart failure, is expensive. ${ }^{13}$ The idea that cardiac surgery is an expensive luxury dies hard, but Morgan et al ${ }^{11}$ have shown that a valve replacement operation costs only $50^{\circ}{ }_{0}$ more than an oesophagectomy. Oesophagectomy is considered to be a necessity, and little thought is given to the cost, even though the operative mortality is high and the long-term survival negligible. The advantages of surgical valve replacement for these elderly patients include restoration to full activity, an independent existence, and freedom from dependence on an overstretched medical and social domiciliary service. Not only are the results of surgical treatment much better than those achieved by medical management but the case for valve replacement can also be justified on economic grounds.

\section{References}

${ }_{1}^{1}$ British Medical fournal, 1968, 4, 530.

2 Wheeldon, D R, et al, Thorax, 1976, 31, 565.

${ }^{3}$ Hochberg, M S, et al, Archives of Surgery, 1977, 112, 1475.

4 Austen, W G, et al, fournal of the American Medical Association, 1970, 211, 624 .

5 Oh, W, et al, British Heart fournal, 1973, 35, 174.

6 Waddy, J L, and Sutherland, H D, Medical fournal of Australia, 1973, 1, 1105 .

' Barnhorst, D A, et al, Annals of Thoracic Surgery, 1974, 18, 81.

${ }^{8}$ Roberts, W C, Circulation, 1970, 42, 91.

${ }^{9}$ Roberts, W C, Perloff, J K, and Constantino, T, American fournal of Cardiology, 1971, 27, 497.

${ }^{10}$ Schlatmann, T J M, and Becker, A E, American fournal of Cardiology, 1977, 39, 13.

${ }^{11}$ Morgan, K, Didsbury, F, and Braimbridge, M, Thorax. In press.

12 Ross, K. To be published.

13 Opit, L J, British Medical fournal, 1977, 1, 30.

\title{
Treating heartburn in pregnancy: comparison of acid and alkali mixtures
}

\author{
R D ATLAY, A R L WEEKES, G D ENTWISTLE, D J PARKINSON
}

British Medical fournal, 1978, 2, 919-920

\section{Summary and conclusions}

A randomised crossover trial was performed in 55 pregnant women who complained of heartburn to see whether alkali or acid treatment alleviated it. Each woman was given a week's treatment with an acid mixture, an alkali mixture, and a placebo in randomised order. Both acid and alkali mixtures were better than placebo, but there was no significant difference between the acid and alkali treatments.

Together with the inconsistent reports of some patients, these findings suggest that both acid reflux and bile regurgitation may cause heartburn in pregnant women and that other factors may also play a part. Because the cause of heartburn may be difficult to determine, treatment should be empirical. If the patient does not respond to seven days' acid treatment an alkali mixture should be prescribed; there is a $98 \%$ chance that one of these treatments will relieve symptoms.

\section{Introduction}

Heartburn occurs in about $70 \%$ of pregnant women. ${ }^{1}$ Its cause, however, is controversial. Regurgitation of gastric contents through an incompetent lower oesophageal sphincter is associated with heartburn, and the acidity is thought to be responsible for the heartburn. ${ }^{2} 3$ Alkali-based treatment has therefore been

\section{Mill Road Maternity Hospital, Liverpool L6 2AH}

R D ATLAY, MRCOG, consultant obstetrician and gynaecologist

A R L WEEKES, FRCSED, MRCOG, senior registrar (now consultant obstetrician and gynaecologist, Rush Green Hospital, Romford)

G D ENTWISTLE, MRCOG, senior registrar

D J PARKINSON; $\mathrm{MB}$, CHB, senior house officer recommended for this condition. More recently the reflux of bile through the pyloric and lower oesophageal sphincters has been shown to be associated with heartburn. ${ }^{14}$ We therefore compared the relative efficacy of acid and alkali mixtures in the treatment of this common problem.

\section{Patients and methods}

A randomised double-blind crossover trial of an acid, an alkali, and a placebo mixture in the treatment of pregnancy heartburn was performed at Mill Road Maternity Hospital over three months.

Fifty-five consecutive patients who complained of a burning discomfort in the epigastrium or retrosternal region were studied. All patients were questioned by DP before and on completion of each seven-day course of treatment. No patients who were taking drugs or had a history of gastrointestinal disease were included in the study. Patients were given an acid, an alkali, and a placebo mixture; random numbers were used to determine the order of treatment. Neither the doctor nor the patient knew the contents of the mixtures. Each patient was advised to take $10 \mathrm{ml}$ of the mixture after meals and before going to bed. Each mixture was prescribed for seven days and between crossover from one mixture to another no treatment was given for four days. Details were recorded of age, parity, socioeconomic class, and the gestational age at which heartburn first occurred. We then assessed the effect of the treatment to see whether symptoms disappeared, improved, showed no change, or became worse.

The acid mixture had a $\mathrm{pH}$ of 2 and contained dilute hydrochloric acid $0.1 \mathrm{ml}$ in $10 \mathrm{ml}$. The alkali mixture had a $\mathrm{pH}$ of 9 and contained sodium bicarbonate $0.5 \mathrm{~g}$ in $10 \mathrm{ml}$. Both mixtures contained similar proportions of syrup, amaranth solution, and chloroform water. The placebo mixture was neutral and contained only amaranth and chloroform water. All three mixtures were the same colour.

$\chi^{2}$ Tests, Kendall's rank correlation coefficient, one-factor analysis of variance, and discriminant functions analysis were used to assess significance of differences between the two groups.

\section{Results}

Forty-one patients took all three mixtures, five took two mixtures, and nine stopped treatment after one mixture. Table I shows that a similar proportion of patients found their symptoms relieved by the 
TABLE I-Response to treatment after acid alkali and neutral drug treatment in the 41 women who completed the trial. (Percentages in parentheses.)

\begin{tabular}{|c|c|c|c|c|c|}
\hline Symptoms & & Alkali & Acid & Placebo & Total \\
\hline $\begin{array}{l}\text { Disappeared or improved } \\
\text { No change or worse }\end{array}$ & 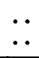 & $\begin{array}{l}21(51) \\
20(49)\end{array}$ & $\begin{array}{l}28(68) \\
13(32)\end{array}$ & $\begin{array}{l}18(44) \\
23(56)\end{array}$ & $\begin{array}{l}67 \\
56\end{array}$ \\
\hline Total & .. & 41 & 41 & 41 & 123 \\
\hline
\end{tabular}

Alkali $v$ acid: $\chi^{2}=1 \cdot 826 ; \mathrm{DF}=1 ; \mathrm{P}=0.18$.

Alkali $v$ placebo: $\chi^{2}=0.196 ; D F=1 ; P=0.66$.
Acid $v$ placebo: $\chi^{2}=4.011 ; D F=1 ; P=0.045$.
TABLE II-Response to treatment after acid, alkali, and neutral drug treatment in all women who entered the trial

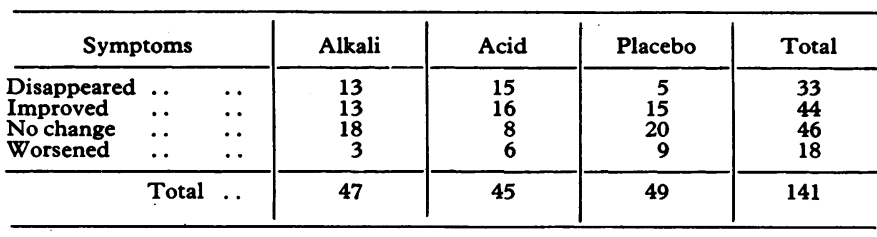

Alkali $v$ acid (acid better): $\chi^{2}$ for trend $=0.3666 ; P=0.55$.

Alkali $v$ placebo (alkali better) $: \chi^{2}$ for trend $=5.305 ; P=0.021$.
Acid $v$ placebo (acid better): $\chi^{2}$ for trend $=7.527 ; P=0.006$.

TABLE III-Response to treatment in relation to maternal age, parity, trimester, and socioeconomic class

\begin{tabular}{|c|c|c|c|c|c|c|c|c|c|c|c|c|c|c|}
\hline & & & \multicolumn{4}{|c|}{ Alkali $v$ acid } & \multicolumn{4}{|c|}{ Alkali $v$ placebo } & \multicolumn{4}{|c|}{ Acid $v$ placebo } \\
\hline & & & $\begin{array}{l}\text { Alkali } \\
\text { better }\end{array}$ & $\underset{\text { acid }}{\text { Alkali }}=$ & $\begin{array}{c}\text { Acid } \\
\text { better }\end{array}$ & Total & $\begin{array}{l}\text { Alkali } \\
\text { better }\end{array}$ & $\begin{array}{l}\text { Alkali }= \\
\text { placebo }\end{array}$ & $\begin{array}{c}\text { Placebo } \\
\text { better }\end{array}$ & Total & $\begin{array}{c}\text { Acid } \\
\text { better }\end{array}$ & $\begin{array}{l}\text { Acid }= \\
\text { placebo }\end{array}$ & $\begin{array}{c}\text { Placebo } \\
\text { better }\end{array}$ & Total \\
\hline \multirow[t]{2}{*}{$\begin{array}{r}\text { Age } \\
<20 \ldots \\
20-24 \ldots \\
25-29 \ldots \\
\geqslant 30 \ldots \\
\end{array}$} & $\begin{array}{l}\because \\
\because \\
\cdots\end{array}$ & $\begin{array}{l}\cdots \\
\cdots \\
\cdots\end{array}$ & $\begin{array}{l}3 \\
3 \\
6 \\
3\end{array}$ & $\begin{array}{l}0 \\
3 \\
0 \\
0\end{array}$ & $\begin{array}{l}4 \\
9 \\
6 \\
4\end{array}$ & $\begin{array}{r}7 \\
15 \\
12 \\
7\end{array}$ & $\begin{array}{l}2 \\
9 \\
8 \\
3\end{array}$ & $\begin{array}{l}4 \\
0 \\
3 \\
1\end{array}$ & $\begin{array}{l}2 \\
7 \\
2 \\
3\end{array}$ & $\begin{array}{r}8 \\
16 \\
13 \\
7\end{array}$ & $\begin{array}{l}4 \\
9 \\
9 \\
1\end{array}$ & $\begin{array}{l}0 \\
5 \\
1 \\
4\end{array}$ & $\begin{array}{l}3 \\
2 \\
2 \\
3\end{array}$ & $\begin{array}{r}7 \\
16 \\
12 \\
8\end{array}$ \\
\hline & Total & . & 15 & $=7 \cdot 19 ; \mathrm{D}$ & $6 ; \stackrel{23}{P=0.30}$ & 41 & 22 & $11.34 ; \mathrm{I}$ & $=6 ; \stackrel{14}{P}=0$. & 44 & 23 & $=12 \cdot 14 ; \mathrm{DI}$ & $=6 ; P^{10}=0.059$ & 43 \\
\hline \multicolumn{2}{|l|}{$\begin{array}{l}\text { Parity } \\
\quad \text { Primiparous ... } \\
\text { Multiparous .. } \\
\end{array}$} & $\because$. & $\begin{array}{r}10 \\
5 \\
\end{array}$ & $\begin{array}{l}3 \\
0 \\
\end{array}$ & $\begin{array}{l}11 \\
12 \\
\end{array}$ & $\begin{array}{l}24 \\
17 \\
\end{array}$ & $\begin{array}{r}14 \\
8 \\
\end{array}$ & $\begin{array}{l}4 \\
4 \\
\end{array}$ & $\begin{array}{l}7 \\
7 \\
\end{array}$ & $\begin{array}{l}25 \\
19 \\
\end{array}$ & $\begin{array}{r}15 \\
8 \\
\end{array}$ & $\begin{array}{l}5 \\
5 \\
\end{array}$ & $\begin{array}{l}4 \\
6 \\
\end{array}$ & $\begin{array}{l}24 \\
19 \\
\end{array}$ \\
\hline & Total & . & 15 & $=3.62 ; \mathrm{D}$ & $=2 ; \stackrel{23}{P}=0.16$ & 41 & 22 & $\begin{array}{c}8 \\
=0.83 ; D\end{array}$ & $=2 ; \stackrel{14}{P}=0$ & 44 & 23 & $\begin{array}{l}10 \\
=1.98 ; \mathrm{DI}\end{array}$ & $=2 ; \stackrel{10}{P}=0.37$ & 43 \\
\hline \multirow[t]{2}{*}{$\begin{array}{c}\begin{array}{c}\text { Trimester } \\
\text { 1st } \\
\text { 2nd }\end{array} \\
\text { 3rd }\end{array}$} & $\because$ & $\begin{array}{l}\cdots \\
\cdots\end{array}$ & $\begin{array}{l}3 \\
5 \\
7 \\
\end{array}$ & $\begin{array}{l}0 \\
2 \\
1\end{array}$ & $\begin{array}{r}6 \\
10 \\
7 \\
\end{array}$ & $\begin{array}{r}9 \\
17 \\
15 \\
\end{array}$ & $\begin{array}{l}6 \\
8 \\
8 \\
\end{array}$ & $\begin{array}{l}1 \\
4 \\
3 \\
\end{array}$ & $\begin{array}{l}4 \\
5 \\
5 \\
\end{array}$ & $\begin{array}{l}11 \\
17 \\
16\end{array}$ & $\begin{array}{r}4 \\
12 \\
7\end{array}$ & $\begin{array}{l}2 \\
2 \\
6\end{array}$ & $\begin{array}{l}3 \\
4 \\
3\end{array}$ & $\begin{array}{r}9 \\
18 \\
16\end{array}$ \\
\hline & Total & . & 15 & $=2 \cdot 25 ; \mathrm{D}$ & $=4 ; P=0.69$ & 41 & 22 & $=0.95 ; \mathrm{D}$ & $=4 ; \stackrel{14}{P}=0.9$ & 44 & 23 & $=4.09 ; \mathrm{DI}$ & $=4 ; P=0.39$ & 43 \\
\hline \begin{tabular}{ccc}
\multicolumn{3}{l}{ Socioeconomic c } \\
2 & $\ldots$ & \\
3 & $\ldots$ & \\
4 & $\ldots$ & \\
5 & $\ldots$ & \\
\end{tabular} & $\begin{array}{l}\text { class } \\
\cdots \\
\cdots \\
\cdots \\
\end{array}$ & $\begin{array}{l}\cdots \\
\cdots \\
\end{array}$ & $\begin{array}{l}0 \\
4 \\
7 \\
4 \\
\end{array}$ & $\begin{array}{l}2 \\
0 \\
1 \\
0\end{array}$ & $\begin{array}{r}1 \\
7 \\
11 \\
4 \\
\end{array}$ & $\begin{array}{r}3 \\
11 \\
19 \\
8 \\
\end{array}$ & $\begin{array}{r}2 \\
6 \\
10 \\
4 \\
\end{array}$ & $\begin{array}{l}0 \\
2 \\
3 \\
3 \\
\end{array}$ & $\begin{array}{l}1 \\
3 \\
8 \\
2 \\
\end{array}$ & $\begin{array}{r}3 \\
11 \\
21 \\
9\end{array}$ & $\begin{array}{r}2 \\
7 \\
10 \\
4 \\
\end{array}$ & $\begin{array}{l}1 \\
4 \\
3 \\
2 \\
\end{array}$ & $\begin{array}{l}0 \\
1 \\
6 \\
3\end{array}$ & $\begin{array}{r}3 \\
12 \\
19 \\
9\end{array}$ \\
\hline & Total & . & $15 x$ & $17 \cdot 89^{3} ; \mathrm{DI}$ & $6 ; P=0.0065$ & 41 & 22 & $2 \cdot 8$ & $6 ; P=0.8$ & 44 & 23 & $=4 \cdot 21 ; \mathrm{DI}$ & $=6 ; P=0.65$ & 43 \\
\hline
\end{tabular}

alkali mixture and by the acid mixture. The alkali mixture and the placebo mixture were also comparable, but significantly more patients got symptomatic relief from the acid mixture than from the placebo mixture. When the results in all 55 patients were analysed for distribution among the four response categories acid and alkali mixtures produced significantly better results than the placebo. The proportion of patients whose symptoms were improved by the acid mixture was similar to that for the alkali mixture (table II).

Of the 41 subjects who received both acid and alkali mixtures, 40 reported improvement of the symptoms with either or both of the mixtures. Twenty-two out of 41 reported disappearance of the symptoms with one or other (but never with both). Among the 41 patients who received all three mixtures only two patients found the placebo mixture better than both acid and alkali. The estimated probability of complete relief with either acid or alkali was $54 \%(22 / 41), 95 \%$ confidence limits of $37 \%$ to $69 \%$; the estimated probability of some amount of relief with either acid or alkali mixture was $98 \%(40 / 41)$, with $95 \%$ confidence limits of $87 \%$ to $99.9 \%$.

The response to treatment did not depend significantly on parity, social class (with one exception), or the duration of the pregnancy at the onset of the symptoms (table III). This was also confirmed by Kendall's rank correlation coefficient and one-factor analysis of variance. No discriminant functions of response on combinations of these variables were significant. The response to treatment was also not significantly related to the order in which the drugs were administered.

Fourteen of the 41 patients showed an inconsistent response. They found the placebo mixture either better or worse than both A and B. An intermediate response would have been expected to placebo in all cases.

\section{Discussion}

We found that both the acid and the alkali mixtures were better than the placebo, but there was no significant difference between the proportions of patients who responded to the acid and alkali mixtures. This applied irrespective of maternal age, parity, social class, or gestational age. These findings suggest that either acid reflux or bile regurgitation may cause pregnancy heartburn. The inconsistent response noted in some patients suggests that other factors may be important in either causing or aggravating pregnancy heartburn. We do not suggest that the exact cause be determined in each individual, as the tests are $\dot{\delta}$ time consuming, distressing, and potentially dangerous. The response to treatment would be an equally accurate method of $\frac{\rho}{9}$ diagnosis.

We suggest that pregnancy heartburn should be treated in $\mathscr{N}$ the first instance with an acid mixture; if the patient does not $\frac{D}{O}$ respond after seven days an alkali mixture can be prescribed with a $98 \%$ chance of symptomatic relief from one or the other.

We thank Mr C R West, Biostatistics Unit, New Medical School, University of Liverpool, for his help with the design of the study and the statistical analysis, and our pharmacist Mr W Baker, whose help was invaluable.

\section{References}

${ }^{1}$ Atlay, R D, Gillison, E W, and Horton, A L, fournal of Obstetrics and Gynaecology of the British Commonwealth, 1973, 80, 1.

2 Tuttle, S G, and Grossman, M I, Proceedings of the Society for Experimental Biology, 1958, 98, 225.

3 Bernstein, L M, and Baker, L A, Gastroenterology, 1958, 34, 760.

4 Gillison, E W, Nyhus, L M, and Duthie, H L, British fournal of Surgery, $1971,58,864$. 